\title{
Ann Curthoys, Ann McGrath, How to Write History that People Want to Read, Palgrave Macmillan 2011, ss. 265*
}

O ile recenzje naukowe w porównaniu z tradycyjnymi ukazują się trochę później, o tyle publikacja takiej dekadę po premierze książki może wydawać się przesadą. Praca australijskich badaczek Ann Curthoys i Ann McGrath odbiła się sporym echem w literaturze przedmiotu (31 wyników w Google Scholar, mimo zawodności tego narzędzia, daje pewne wyobrażenie) i figuruje w sylabusach zajęć na anglojęzycznych uczelniach (University of Calgary, University of Edinburgh, University of Oregon) ${ }^{1}$. Tymczasem w Polsce pozostaje nieznana ${ }^{2}$. To akurat nie dziwi, bo nigdy nie byliśmy zalewani taką liczbą publikacji historycznych jak dziś. Sama Bibliografia Historii Polskiej odnotowuje kilka tysięcy rocznie, a internet zapewnił dostęp do literatury zagranicznej w skali niespotykanej.

Nie chciałbym szarżować, mówiąc, że każdy polski historyk powinien przeczytać How to Write History that People Want to Read, ale wypadałoby, aby zastanowił się nad tytułowym pytaniem. Historia, jak żadna inna nauka, daje możliwości pisania prac łączących walory naukowe i literackie. Niestety pozostaje zazwyczaj zmarnowaną okazją, bo na ogół publikacje historyków akademików są napisane fatalnie nie tylko zresztą w Polsce.

Z tym problemem postanowiły zmierzyć się dwie doświadczone australijskie badaczki, Ann Curthoys i Ann McGrath. Obie zajmują się i klasycznie rozumianą historią, i teoretycznymi aspektami pisarstwa historycznego ${ }^{3}$. W przypadku How to Write History that People Want to Read tytuł dobrze oddaje poradnikowy charakter pracy. We wstępie autorki wyjaśniają: „Niezależnie, czy piszesz pracę naukową, czy popularnonaukową, musisz napisać ją dobrze, by czytelnik zwrócił na nią uwagę

* Książka została wydana w Australii w 2009 r. przez UNSW Press, dwa lata później w Wielkiej Brytanii przez Palgrave Macmillan. Korzystałem z tego ostatniego wydania, z którym zapoznałem się w styczniu 2020 r. w trakcie kwerendy w British Library w Londynie. Przeprowadzenie kwerendy było możliwe dzięki stypendium Fundacji z Brzezia Lanckorońskich.

1 Recenzje: B. Scates, „Labour History” 2010, t. 99, s. 229-231; A. Munslow, „Rethinking History” 2013, t. 17, nr 2, s. 282-291 (non vidi).

${ }^{2}$ Brak jej w katalogach Biblioteki Narodowej i Biblioteki Jagiellońskiej. Nie spotkałem się z żadną pracą polskiego badacza, który by ją cytował.

3 O Curthoys: S.M. Harrison, Curthoys, Anna (1945-), The Encyclopedia of Women \& Leadership in Twentieth-Century Australia, http://www.womenaustralia.info/leaders/biogs/WLE0504b.htm (dostęp: 8.03.2020); Professor Ann Curthoys, University of Sydney, https://sydney.edu.au/arts/history/staff/profiles/curthoys.shtml (dostęp: 8.03.2020). O McGrath: Professor Ann McGrath, Australian National University, https:/history.cass.anu.edu.au/centres/acih/people/professor-ann-mcgrath (dostęp: 8.03.2020). 
i skupił się na niej. To jest cel tej książki - pomóc zdobyć najszersze możliwe grono czytelników dla twojej pracy. Nie twierdzimy, że znamy sekret pisania historycznych bestsellerów, chociaż, jak na prace akademickie, niektóre nasze książki sprzedały się bardzo dobrze, to - o ile nam wiadomo - nie były sprzedawane na lotniskach”.

How to Write History that People Want to Read w założeniach jest pracą skierowaną do szerokiego grona osób zajmujących się rozmaicie pojętym pisarstwem historycznym (wymienieni są nawet twórcy podcastów). Została podzielona na jedenaście rozdziałów, przy czym pierwsze pięć stanowi bardziej wprowadzenie do tematu dla początkujących ${ }^{4}$. Odpowiedzi na tytułowe pytanie pojawiają się mniej więcej w połowie książki.

Rozdział szósty, Once upon a time: Beginnings and Endings, zawiera uwagi na temat tytułów książek. Wielu historyków lubi dwuczęściowe: krótki tytuł buduje nastrój i przykuwa uwagę, długi podtytuł wyjaśnia, o czym dokładnie traktuje. Autorki jako przykłady wskazują Somme Mud: The Experiences of an Infantryman in France, 1916-1919, Ordered to Die: A History of the Ottoman Army in the First World War czy The Cheese and the Worms: The Cosmos of a Sixteenth Century Miller, znaną w polskim thumaczeniu jako Ser i robaki. Wizja świata pewnego mlynarza z XVI w. ${ }^{5}$ Również w Polsce stosuje się tę metodę. Dobrym przykładem jest chociażby Zarobić na duszne zbawienie. Religijność chłopów małopolskich od połowy XVI do końca XVIII wieku Tomasza Wiślicza ${ }^{6}$.

Australijskie badaczki radzą stosować tę samą „dwuczęściową metodę” przy tytułach artykułów ${ }^{7}$. Tytuły rozdziałów powinny być raczej informatywne, przedmowa ma być osobista, ale nie należy przesadzać. Początek pierwszego rozdziału musi przykuwać uwagę. Bardzo interesujące jest zestawienie fragmentu książki Iaina McCalmana The Seven Orders of Count Cagliostro: The Greatest Enchanter of the Eighteenth Century z wymyśloną wersją utrzymaną w akademickim żargonie.

Curthoys i McGrath sugerują, że można zacząć od opisu ciekawego epizodu, interesującego przypadku, by później przejść do bardziej akademickich rozważań. Widać tutaj pewną analogię do warsztatu scenarzysty filmowego, gdzie obowiązuje zasada „pierwszych dziesięciu stron” (ewentualnie piętnastu) - jeżeli do tego momentu nie wzbudzi się zainteresowania recenzenta lub producenta, praca ląduje w koszu.

Według autorek zakończenie w jakiś sposób powinno nawiązywać do początku książki. Tutaj też widać analogię do pisania scenariuszy filmowych. Lew Hunter,

${ }^{4} \mathrm{Z}$ tytułami rozdziałów oraz ich początkowymi fragmentami można zapoznać się na stronie wydawcy: https://www.palgrave.com/gp/book/9780230290389 (dostęp: 8.03.2020).

${ }_{5}^{5}$ C. Ginzburg, Ser i robaki. Wizja świata pewnego mlynarza z XVI w., thum. R. Kłos, Warszawa 1989.

${ }^{6}$ T. Wiślicz, Zarobić na duszne zbawienie. Religijność chlopów małopolskich od polowy XVI do końca XVIII wieku, Warszawa 2001.

${ }^{7}$ Przykładem dobrego zastosowania tej metody w polskiej historiografii jest: D. Kołodziejczyk, Tibet in the Crimea? Polish embassy to the Kalmyks of 1653 and a project of an anti-Muslim alliance, "Acta Poloniae Historica” 2016, t. 114, s. 231-253.

${ }^{8}$ S. Field, R. Rilla, Pisanie scenariusza filmowego, thum. W. Wertenstein, B. Pankau, Warszawa 1998, s. 60-73 (Field proponuje zasadę 10 stron); M. Karpiński, Scenariusz: Niedoskonałe odbicie filmu, wyd. 2, Kraków 2004, s. 199-211. 
autor jednego z najpopularniejszych amerykańskich podręczników scenopisarskich, twierdzi, że w pierwszej scenie warto „nawet delikatnie przygotować widza na zakończenie", wskazując na przykłady Obywatela Kane'a (Różyczka na początku i na końcu), E.T. (kosmita ląduje - odlatuje) i Casablanki (samolot na początku i na końcu) ${ }^{9}$.

Rozdział siódmy, Narrative, plot, action!, traktuje o narracji i strukturze. Autorki przywołują opinię amerykańskiego historyka Petera Gaya, że „Historyczna narracja bez analizy jest trywialna, historyczna analiza bez narracji jest niekompletna”. Zdaniem badaczek, pisząc o przeszłości, po pierwsze powinniśmy sprawić, by czytelnicy przejmowali się losem głównych bohaterów, a po drugie utrzymać ich w niepewności, co dalej nastąpi. Historyk oczywiście jest wszechwiedzącym narratorem, ale może tak jak cytowana w książce Barbara Tuchman, opisująca prace nad Sierpniowymi strzatami - pisać tak, jakby nie wiedział, co dalej nastąpi i jak skończy się opowieść. Przy okazji teoretycznych rozważań zostają przywołani Roland Barthes i Michel Foucault.

Autorki zwracają uwagę, że biografie są najpopularniejszym gatunkiem pisarstwa historycznego, tym większa szkoda, że nie wspomniały o pracy amerykańskiego literaturoznawcy Josepha Campbella Bohater o tysiacu twarzy, gdzie przedstawia archetyp podróży bohatera, czy o Podróży autora Christophera Voglera, który - jak to ładnie ujął Maciej Karpiński - przełożył teorie Campbella na język praktyki filmowej ${ }^{10}$. Tymczasem model „,podróży bohatera”, tak popularny wśród hollywoodzkich scenarzystów, można z powodzeniem stosować w pracach historycznych ${ }^{11}$.

Rozdział ósmy, Styling pasts for presents, poświęcony jest zagadnieniom dotyczącym szeroko rozumianego stylu. Autorki poruszają tematy związane z rytmem opowieści, używaniem współczesnego języka czy poprawnością polityczną (np. kwestia słowa Negroes). Zwracają uwagę, że historycy zbyt często używają strony biernej.

Rozdział dziewiąty, Character and emotion, zawiera radę, by pisząc o przeszłości, pamiętać o pięciu zmysłach: wzroku, słuchu, węchu, smaku i dotyku, by pytać, co nasi bohaterowie widzieli, czuli i słyszeli. Ma to nam pomóc zachować świadomość, że historia dotyczy ludzi.

Ciekawe są uwagi autorek na temat dialogów. W połowie XIX wieku badacze przeszłości uznali wymyślanie przemówień za tabu, tymczasem one są zdania, że „czasami istnieje możliwość napisania historycznie wiarygodnej przemowy”, posiłkując się listami, pamiętnikami czy protokołami sądowymi. Szkoda, że przy tej okazji nie poruszyły kwestii słynnej Wioski heretyków Emanuela Le Roy Ladurie, gdzie autor zapędził się z wymyślaniem dialogów ${ }^{12}$. Jako regułę proponują używać krótkich cytatów, zastrzegając, że każdą regułę można złamać.

${ }^{9}$ L. Hunter, Kurs pisania scenariuszy. Od pomystu, przez treatment po pierwsza wersje, thum. T. Szafrański, Myślenice 2013, s. 172-173.

10 J. Campbell, Bohater o tysiacu twarzy, tłum. A. Jankowski, Kraków 2013; Ch. Vogler, Podróż autora. Struktury mityczne dla scenarzystów i pisarzy, tłum. K. Kosińska, Warszawa 2010. Określenie o przekładzie za: M. Karpiński, Scenariusz..., s. 137.

${ }^{11}$ Campbella i Voglera pomija również S.J. Pyne, Voicing and Vision: A Guide to Writing History and Other Serious Nonfiction, Cambridge, Massachusetts-London 2009.

${ }^{12}$ Najlepsze omówienie kwestii związanych ze słynną książką: D.A. Sikorski, Jak historyk potyka się o antropologię historyczna, „Kwartalnik Historyczny” 2011, t. 118, nr 3, s. 495-505. Zob. też 
Rozdział dziesiąty, Footnote fetishism. Quotes and Notes, porusza sprawy związane z przypisami. W pracach naukowych zasady są proste, gorzej w przypadku prac popularnonaukowych (swoją drogą, jak wielu polskich historyków nie potrafi poprawnie zapisać słowa „popularnonaukowy”). Zwracają uwagę, że historycy piszący dla szerszej publiczności ograniczają przypisy do minimum albo w ogóle z nich rezygnują, zastępując je bibliograficznym esejem na końcu książki. Tę ostatnią praktykę znamy z własnego podwórka, chociażby z serii o historii państw wydawanej przez Ossolineum. Sugerują, by w takich przypadkach umieścić przypisy na stronie internetowej. Takie rozwiązanie kilka lat wcześniej zastosowała sama Ann Cuthoys ${ }^{13}$.

Być może rzeczywiście przypisy dolne odstraszają czytelników, bo kojarzą się z pracami naukowymi, a z kolei prace naukowe zwykle są źle napisane. Odwołując się jednak do własnego doświadczenia, mogę stwierdzić, że przypisy końcowe, nawet liczne, nie wpływają negatywnie na wyniki sprzedaży.

W jedenastym rozdziale, Though love. Editing and Revising, mowa jest o kwestiach związanych z redakcją prac. Pojawiają się tam rady oczywiste, jak unikanie kalk (ile wyświechtanych metafor znamy z naszego podwórka!) czy wyrzucanie niepotrzebnych słów.

Podsumowując, poradnik dobrze się czyta. Autorki ze względu na swoje doświadczenie skupiają się na pisaniu tekstów naukowych, co jednak zaburza proporcje. Być może rozwiązaniem byłoby zaangażowanie trzeciego autora, który funkcjonuje poza akademią. Spośród historyków mieszkających w Australii byłbym ciekawy głosu Giordano Nanniego, który obronił doktorat na University of Melbourne, ale zdecydował się opowiadać o historii za pomocą teatru i internetu (vide głośna seria Honest Government Ads, gdzie m.in. krytykowano datę 26 stycznia jako termin Australia Day). Mimo wszystko warto zapoznać się z niektórymi rozdziałami recenzowanej książki, bo w niejednej pracy naukowej tkwi potencjał na sukces czytelniczy, który jest marnowany przez autorów, bo albo nie starcza im talentu, albo nie chce im się pracować nad tym aspektem swojej twórczości.

Nie łudzę się, że książka How to Write History that People Want to Read zrewolucjonizuje opowiadanie o przeszłości w Polsce - nawet gdyby lepiej uwzględnić perspektywę historyków spoza akademii. Na studiach historycznych brak zajęć $\mathrm{z}$ creative writing, a warsztat pisarski większości historyków naukowców jest słaby. Nie zanosi się na poprawę, tym bardziej że w konkursach na stanowiska nauczycieli akademickich, mimo wszystko w większości będących fikcją, nie przykłada się wagi do działań popularyzatorskich kandydatów ${ }^{14}$.

E. Domańska, ,Montaillou - ziemia obiecana błędów” [w:] E. Le Roy Ladurie, Montaillou - wioska heretyków 1294-1324, tłum. E.D. Żółkiews ska, wyd. 2, Poznań 2014, s. 5-23.

${ }^{13}$ A. Curthoys, Freedom Ride: A Freedomrider Remembers, Sydney 2002. Przypisy są dostępne pod adresem: https://webarchive.nla.gov.au/awa/20030720065809/http://arts.anu.edu.au/history/curthoys/endnotes.htm (dostęp: 8.03.2020). Co godne odnotowania, strona została zarchiwizowana w archiwum cyfrowym National Library of Australia.

${ }^{14}$ O konkursach: Otwarte $i$ uczciwe konkursy na stanowiska nauczycieli akademickich - reguta czy wyjątek?, red. R. Pawłowski, D. Rafalska, Warszawa 2016. Raport jest dostępny on-line: https://issuu.com/tlewin/docs/watchdog_5_2016 (dostęp: 7.03.2020). Postulat większego znaczenia działalności popularyzatorskiej w ocenie kandydata na stanowiska nauczyciela akademickiego znalazł 
Przykucie uwagi czytelników pozostaje odległym celem dla pracowników naukowych. Pisze się, aby uzyskać doktorat, habilitację, profesurę, rozliczyć grant, zdobyć dla uczelni osławione ,punkty”. Czy jednak warto trawić kilkadziesiąt lat życia na pisaniu tekstów, których nikt nigdy poza recenzentami i garstką koleżanek i kolegów nie zechce przeczytać?

Michael Morys-Twarowski (D) http://orcid.org/0000-0002-8803-2335

$\bowtie \quad$ Adres do korespondencji: morystwarowski@gmail.com

się wśród rekomendacji wymienionych w Raporcie końcowym z monitoringu otwartych postępowań konkursowych na stanowiska nauczycieli akademickich, http://konkursy.polska.edu.pl/content/Raport $\% 20 \mathrm{ko} \% \mathrm{C} 5 \% 84$ cowy $\% 20 \mathrm{w} \% 20$ monitoringu $\% 20$ konkurs $\% \mathrm{C} 3 \% \mathrm{~B} 3 \mathrm{w} \% 20-\% 20$ rekomendacje $\% 20$ ekspert\%C3\%B3w.pdf (dostęp: 8.03.2020). 
